\title{
Vypustit nebo znovu využít?
}

\section{MARTINA BERÁNKOVÁ, DAGMAR VOLOŠINOVÁ, LADA STEJSKALOVÁ, ELŽBIETA ČEJKA}

Klíčová slova: šedé vody - separační toalety - znovuvyužití odpadních vod

\section{SOUHRN}

V souvislosti s klimatickými změnami, které přinášejí stále větší nerovnoměrnosti v distribuci srážek, dochází ke strrídání období sucha a období, kdy je vody nadbytek, a může docházet k větším či menším povodním.

Postupy, jak se s povodněmi vyrovnávat a jejich následky zmírňovat, jsou již v zásadě, vzhledem k historickým zkušenostem, zpracované. Nová situace nastává s obdobím sucha. S touto situací se budeme muset vyrovnávat a postupy, kdy a jaká opatření přijímat, nás teprve čekají. Bude se i měnit prístup k současným zdrojům vody, ať už povrchovým, či podzemním.
Česká republika jako země, která leží na rozvodí, je prakticky odkázána na množství srážkových vod. Z tohoto důvodu je zvlášt důležité co možná nejvíce využívat veškerou vodu, která na naše území spadne, a zabránit ji v rychlém odtoku z našeho území. Jednou z možností, jak ušetřit zdroje vody, je vodu opakovaně využívat tam, kde je to možné. Na prvním místě stojí využití málo znečištěných vod pro další činnosti nebo znovuvyužití vyčištěné odpadní vody, která v řadě případů je lepší kvality než voda povrchová.

V zemích, jako je USA, Austrálie, Izrael, Švédsko, Holandsko a další, se zabývají rozdělováním odpadních vod u zdroje a využiváním šedých a vyčištěných odpadních vod již dlouhou dobu a mají způsoby využívání velmi propracované.

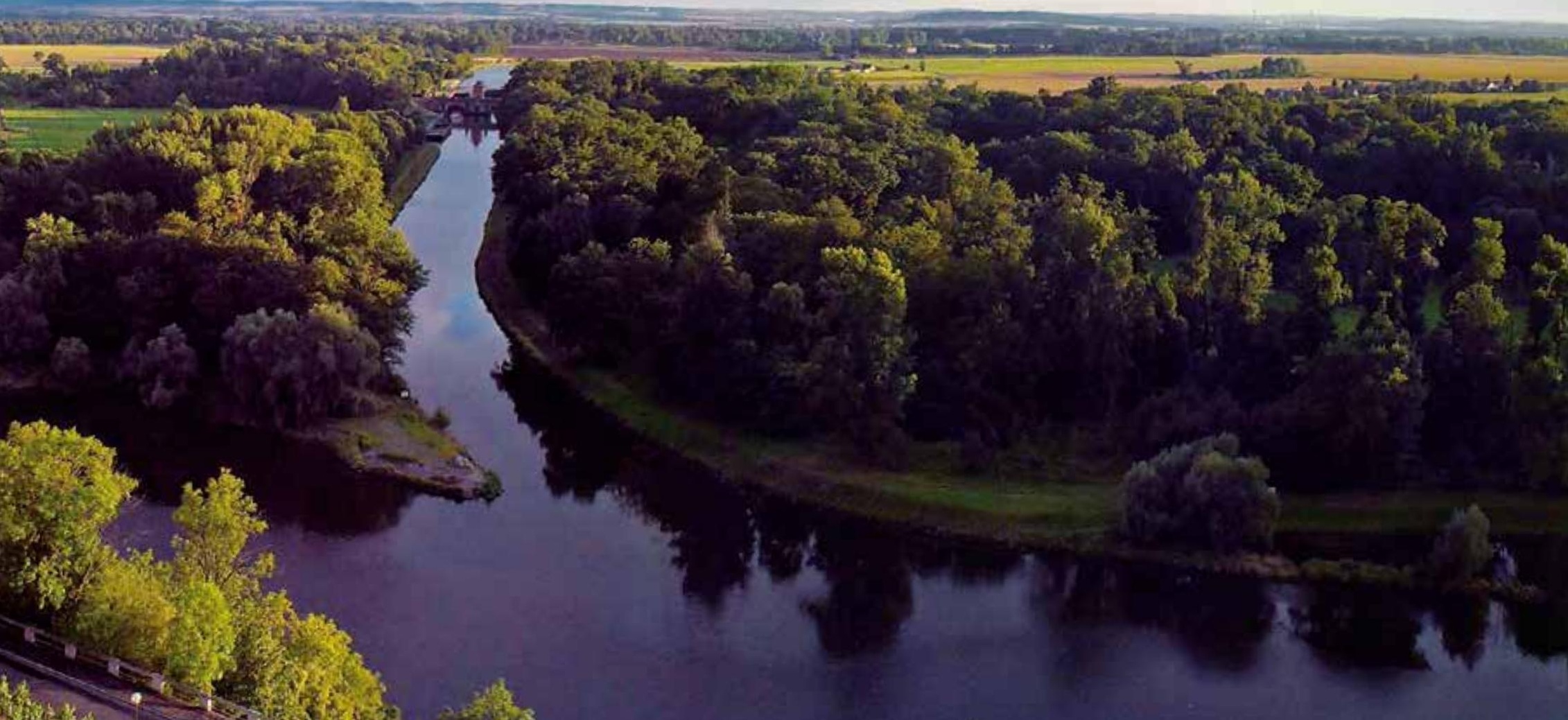




\section{ÚVOD}

V České republice se začalo využívání tzv. šedých vod, tedy vod z umyvadel, sprch a praček, skloňovat ve všech pádech. Jako príklad je možné uvést i prohlášení ministra životního prostředí Richarda Brabce: „Máme celou řadu plánů i s takzvanou šedou vodou, která odchází třeba z umyvadel, a je možno ji opět po zpracování použít ke splachování WC. Splachujeme, stejně jako mnohé jiné evropské země, pitnou vodou, což je barbarství a v některých zemích, včetně třeba Izraele, kde vodou umí šetřit, se to dnes považuje za něco neprípustného." "Žijeme ve vodním blahobytu, ten ale skončil," dodal [1].

Ve Francii jsou už někde zavedeny první suché pisoáry pro veřejnost. Francouzské státní dráhy zahájily u Lyonského nádraží v Pařiži zkušební provoz dvou ekologických „květinových“ pisoárů (obr. 1). Pisoáry obsahují slámu nebo piliny, které umožňují přeměnit moč v hnojivo. Pokud se novinka osvědčí, železniční společnost je připravena objednat pro francouzská nádraží dalších 360 těchto zařízení. Zájem projevilo i vedení města Nantes [2].

$\checkmark$ severní Evropě se již dlouho a ve velké míře používají separační toalety, aby se neplýtvalo pitnou vodou na splachování WC a z ostatních zařízení používajících vodu zbyla jen voda šedá.

V Kalifornii, kde je sucho velkým problémem, mají s využíváním odpadních vod mnoho zkušeností. V Izraeli je znovu využíváno zhruba $90 \%$ vyčištěných odpadních vod, což je nejvíce na světě. Kapková závlaha je dílem izraelských zemědělců [3].

Závlahy vyčištěnými odpadními vodami jsou realizovány napríklad v oblasti Kapského města, v parcích australských měst - v Sydney je to běžné.

Další možností je nepřímé využívání vyčištěných šedých vod nebo i vyčištěných odpadních vod z městských čistíren, kdy tato vyčištěná voda posiluje stávající zdroje povrchové (je vypouštěna do vodárenských nádrží) nebo podzemní (je preses zemní filtry drénována do podloží). Má to ale svá přísná pravidla a omezení. Mezi země, které $v$ regulaci $v$ této oblasti učinily mnoho, řadíme Austrálii [4]. Velmi propracované směrnice regulující znovuvyužití šedých a odpadních vod mají i ve Spojených státech.

Česká republika se rovněž ztotožňuje s myšlenkou efektivního hospodaření s vodou a v obecné rovině podporuje kroky, které Evropská komise navrhla $\checkmark$ Sdělení Komise Evropskému parlamentu, Radě, Evropskému hospodářskému a sociálnímu výboru a Výboru regionů - Uzavření cyklu - Akční plán EU pro oběhové hospodářství [COM (2015) 614; COM (2015) 614/2]. Mimo jiné se Evropská komise zavázala k zavedení opatření, která povedou ke zvýšení efektivity hospodaření s vodou ve smyslu opětovného využívání upravené odpadní vody v bezpečných a nákladově přiznivých podmínkách včetně ustanovení právních předpisů o minimálních požadavcích na opětovné použití vody. Cílem těchto opatření je snížení tlaku na nadměrně využívané vodní zdroje EU stejně jako recyklace živin nahrazující pevná hnojiva v zemědělství.

\section{SPOTŘEBA VODY}

Spotřeba vody je v různých zemích velmi rozdílná. V České republice se průměrná spotřeba pohybuje pod 90 litrů na obyvatele za den. Pro porovnání, Američané spotřebují 300 litrů a Kanadané dokonce 700 litrů [5]. V zemích třetího světa je to 10 litrů na obyvatele za den [6].

$\checkmark$ celosvětovém měřítku je $v$ současné době téměř $70 \%$ užívané vody spotrebováno v zemědělství, zejména k závlahám, průmysl spotřebovává 23\% vody, domácnosti $8 \%$. Struktura spotřeby je ovšem rozdílná v jednotlivých regionech. V Evropě je největším spotřebitelem průmysl s 54\%, zemědělství s 33\% a domácnosti s $13 \%$ vody [7].

Do spotřeby vody je však nezbytné započítat i tu, která není na první pohled patrná tzv. virtuální vodu. To je voda, která se spotřebuje např. při výrobě potravin živočišného původu, výrobků, energií a dalších komodit a není spotřebiteli vnímána [5].

\section{MOŽNOSTI ŠETŘENÍ VODOU V DOMÁCNOSTI}

Jak již bylo uvedeno, domácnosti spotřebovávají 8-13\% vody. Jednou z možností, jak šetřit s pitnou vodou v domácnosti, je nepoužívat ji na splachování toalet. Můžeme na spláchnutí využít již použitou, tzv. šedou, popř. bílou vodu nebo místo splachovacích toalet použivat toalety separační.

\section{Šedé vody}

Šedé vody jsou odpadní vody bez obsahů fekálií a moči, tzn. vody ze sprch, myček, umyvadel, praček. V novějším pojetí se do šedých vod často nezařazuje odpadní voda z kuchyní.

Šedé vody mohou být čištěny $v$ zařízeních, kde se využívají aerobní biologické procesy nebo membránové technologie, které vyčištěnou vodu zbavují většiny virů a bakterií. Často se také na hygienizaci použíá UV lampa na výstupu ze zařízení. Vyčištěná šedá voda se nazývá bílá voda, je kvalitou srovnatelná se srážkovou a použitelná především jako voda provozní pro splachování toalet a zalévání.

Pokud se zaměříme jen na ekonomické hledisko využívání šedých vod, můžeme vycházet z úvahy, že jeden člověk vyprodukuje kolem 50 litrů šedé vody denně. Na splachování záchodu použije kolem 30 až 40 litrů vody denně, tedy při použití nijak neupravené šedé vody lze ušetřit např́klad 35 litrů pitné vody každý den. Při průměrné ceně vody 82 Kč za 1000 litrů je úspora přes 1000 Kč ročně na jednu osobu.

Pokud budeme chtít používat bílou vodu, budeme si muset pořídit například čistící jednotku na její úpravu za cca 95000 Kč. Vycházíme-li ze stejné úvahy, tedy že člověk vyprodukuje 50 litrů šedé vody denně, ale celý její objem znovu využije (splachování WC, mytí auta, chodby aj.), pak návratnost investice na zařizení pro čištění šedé vody bude pro čtyřčlennou domácnost asi 15 let, pro pětičlennou pak 12 let. Toto zařízení má kapacitu 300 litrư denně. Z tohoto důvodu je vhodné ho používat v prípadech větší produkce šedé vody nebo více obyvatel v jednom objektu např. obytné domy, penziony.

\section{Separační toalety}

$\checkmark$ prípadě použití separačních nebo kompostovacích toalet ušetříme vodu na splachování a ještě máme hodnotné hnojivo, které oceníme, zvláště pokud vlastníme zahradu. Ceny separačních a kompostovacích toalet se pohybují od 5000 (kempingové provedení, vhodné spíše jen na občasné použivání) do 100000 (komfortní zařízení). Pro běžné uživatele je vhodná toaleta za 20 až 30 tisíc korun. Jak bylo uvedeno výše, za pitnou vodu se tak ušetři přes 1000 Kč na osobu a rok. Pro pětičlennou domácnost je návratnost ekotoalety 5 let, pokud ovšem nepočítáme to, že nemusíme pořizovat umělé hnojivo na vypěstování vlastní zeleniny.

Při provozování kompostovacích toalet, resp. při nakládání se shromážděnými exkrementy, se jeví jako nejvíce limitující hygienické hledisko. Lidé produkují zhruba 500 litrů moči a 50 litrů výkalů na osobu za rok. Ty obsahují asi 4 kg dusíku, fosforu 0,5 kg a 1 kg draslíku - tři základní prvky pro růst rostlin. Přesné množství se liší region od regionu v závislosti na př́ijmu potravy. Sedmdesát procent živin vylučovaných lidmi je ve frakci moči [8, 9]. Pokud hovoříme o kompostovacích toaletách, predpokládá se, že je nashromážděný materiál hygienizován aerobním rozkladným procesem - kompostováním, tj. rozkladem přeměnou na stabilní humusové látky [10]. Samotné lidské exkrementy kompostovat nelze nebo jen s obtížemi.

K průběhu ideálního kompostovacího procesu je nutné zajistit několik podmínek. Tou nejdůležitější, z hlediska hygienizace, je dosažení teploty $55^{\circ} \mathrm{C}$ po dobu minimálně 21 dnů nebo nad $65^{\circ} \mathrm{C}$ po dobu minimálně 5 dnů [11]. Některé 
komerční kompostovací toalety mají v sobě zabudované ohřívadlo, které podporuje rozkladný proces, ale ani ono úplnou hygienizaci nezaručí. U ostatních toalet, kde hygienizační proces je výsledkem činnosti mikroorganismů mimo toaletu, tj. na kompostovišti, je nutné zajisti vhodné podmínky pro jejich činnost. Tím je co možná nejvíce homogenizované a rádně provzdušněné složení ideální poměr C : N 30 : 1. Exkrementy jsou dusíkatý materiál a je potřeba smíchat je s tzv. uhlíkatým materiálem jako je sláma (C : N 60-110 : 1), tráva (C : N 35-45 : 1), piliny (C : N 100-120 : 1), listí (C : N 32-48 : 1), rostlinné zbytky z kuchyně a zahrady (C : N 30-45: 1). Provzdušňování zajistíme překopáváním. Čas překopávek se řídí podle naměřené teploty kompostu kompostovacím teploměrem [12] Kompostování je třístupňový proces, kdy v 1. stupni nazývaném mesofilní (rozkladný) dochází k intenzivnímu rozvoji bakterií a plísní a rozkladu lehce rozložitelných látek (cukry, škroby, bílkoviny). Optimální teplota je $50-70^{\circ} \mathrm{C}$. V 2. stupni tzv. termofilním (přechodným) se nadále rozvíjejí bakterie a především aktinomycety. Obtížněji se odbourávají organické látky, jako je celulóza a lignin, z kterých vznikají stabilní organické látky obsahující humus. Optimální teplota druhého stupně je $40-45^{\circ} \mathrm{C}$. Ve třetím dozrávajícím stupni dochází ke stabilizaci organických látek, kompost se již nezahřívá, hmota je homogenní a nezapáchá. Teplota je blízká okolní.

Celé nastartování kompostovacího procesu by mělo začít do 4-5 dnů po založení kompostu. Extrémní výkyvy teplot v jednotlivých stupních regulujeme prekekopávkou spojenou podle potřeby i s proléváním/vlhčením kompostu, ať vodou, či nashromážděnou močí ze separační toalety. Dưležitým hlediskem je i množství kompostovaného materiálu. K dosažení hygienizační teploty je ho potřeba min. $1 \mathrm{~m}^{3}$ [13].

S ohledem na hygienizaci není vhodné k zpracování materiálu ze separačních toalet využivat vermikompostování. Optimální teplota pro život žižal je $25^{\circ} \mathrm{C}$. Při zvýšené teplotě hynou [14, 15]. Stejně tak prvoplánově k hygienizaci není vhodné používat vápno, které by pro zvýšení teploty muselo být nehašené (CaO), ale vzhledem k "suchému" materiálu by proces nemusel optimálně a rovnoměrně $\checkmark$ celém objemu materiálu proběhnout. Použití vápna se spíše řídí vybalancováním vhodného rozpětí pH kompostu, které je u čerstvého kompostu 6-8 [16].

Vzniklý kompost se nedoporučuje používat tam, kde by docházelo k přímému kontaktu s konzumovanou zeleninou a ovocem a i trávou zkrmovanou doma chovanými zviřaty např. králíky.

\section{Separační toalety a legislativa}

Všechny komerčně vyráběné a pro náš trh schválené separační a kompostovací toalety mají certifikát CE, který vychází z mezinárodní normy ČSN ISO 14024 a souvisejících právních předpisů Evropské unie [17]. Ekoznačku může získat jen ten výrobek, který prokazatelně je ve všech fázích svého životního cyklu šetrnější k životnímu prostředí i ke zdraví spotřebitele [18].

Konkrétní legislativní předpis, který by se komplexně zabýval provozem ekotoalet neexistuje. Pokud ekotoaleta nebo kompostér nebude stavbou o jednom nadzemním podlaží do $25 \mathrm{~m}^{2}$ zastavěné plochy a do $5 \mathrm{~m}$ výšky, nepodsklepená, nebude obsahovat obytné ani pobytové místnosti a ani vytápění, není potřeba stavební povolení ani se nemusí tato stavba ohlašovat stavebnímu úřadu [19].

Nakládání s materiálem mimo zásobník ekotoalety se řídí následujícími předpisy:

1. občanský zákoník [20]: omezení vlastnického práva odstavec (1) § 1013 vlastník se zdrží všeho, co působí, že odpad, voda, kouř, prach, plyn, pach, světlo, stín, hluk, otřesy a jiné podobné účinky (imise) vnikají na pozemek jiného vlastníka (souseda) v míre nepřiměřené místním poměrům a podstatně omezují obvyklé užívání pozemku; to platí i o vnikání zviŕat. Zakazuje se přímo přivádět imise na pozemek jiného vlastníka bez ohledu na míru takových vlivů a na stupeň obtěžování souseda, ledaže se to opírá o zvláštní právní důvod.

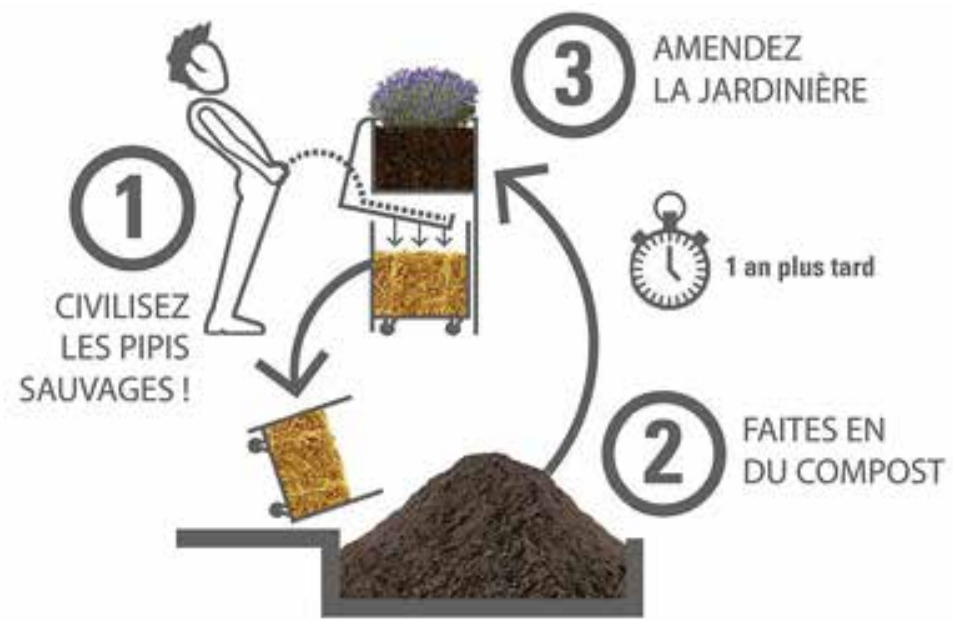

Obr. 1. Suchý veřejný pisoar ve Francii - schéma [2]

Fig. 1. Public urinal without water needs in France - scheme [2]

2. vodní zákon [21]: při nakládání s materiálem z toalety nesmí dojít k ohrožení životního prostředí a zdraví lidí. Při kompostování je nutné dbát, aby nedošlo k úniku látek, které by ohrozily kvalitu povrchových a podzemních vod. Nesmí být umístěny v záplavovém území. Konkrétně se jedná o §§ 23a, 67 a př́lohy č. 1 .

3. vyhláška Ministerstva zemědělství č. 474/2000 Sb. [22]: k hnojení nelze používat organická hnojiva, u nichž je obsah rizikových prvků vyšší než stanoví předpis. Limity rizikových prvků jsou pro statková a organická hnojiva: 2 mg kadmia, $100 \mathrm{mg}$ olova, $1 \mathrm{mg}$ rtuti, 20 mg arsenu, 100 mg chromu, 20 mg molybdenu, 50 mg niklu na jeden $\mathrm{kg}$ sušiny a dále pro:

a) organická a statková hnojiva se sušinou nad 13\%, 150 mg mědi a 600 mg zinku na jeden kilogram sušiny,

b) organická a statková hnojiva se sušinou nejvýše 13\%, 250 mg mědi a 1200 mg zinku na jeden kilogram sušiny.

4. proces kompostování a hygienizace se řídí normou ČSN 465735 - Průmyslové komposty [23]

5. pokud bychom materiál nechtěli využít a chtěli nebo museli se ho zbavit, stal by se odpadem a nakládání s ním by se řídilo podle zákona o odpadech [24]. To znamená, že o odpad vyprodukovaný fyzickou nepodnikající osobou je povinna se postarat príslušná obec, resp. oprávněná osoba, která má oprávnění k nakládání s tímto druhem odpadu.

6. kompostování biologicky rozložitelného odpadu upravuje vyhláška Ministerstva životního prostředí č. 341/2008 Sb. v platném znění [25].

V současné době je využití separačních toalet, resp. šedé vody, nejen legislativně, ale zejména ekonomicky, vzhledem k potřebě dvojitých rozvodů a dalších stavebních úprav, problematické. Jedná se spíše o trend, který bude tím více aktuální, čím citelnější budou související aspekty, jako je nedostatek vody, zvyšující se její cena, tlak na efektivitu čištění odpadních vod a v neposlední řadě i existence či spíše neexistence vhodného recipientu pro vyčištěné odpadní vody. I v naší republice jsou oblasti, kde z různých důvodů, nejčastěji nedostatku financí, není a ani výhledově nebude jak veřejný vodovod, tak ani kanalizace. Podle Statistické ročenky České republiky 2016 byl podíl obyvatel trvale bydlících $v$ domech napojených na kanalizace pro veřejnou potřebu $84,2 \%$ [26]. Pro zbylých 15,8\% je tento prístup nejen ekologický, ale 
život umožňující. Předpokladem pro označení ekologický je však nejen úspora vody, ale i používání pro prírodu šetrných lehce odbouratelných prostředků pro osobní hygienu, praní či mytí nádobí, které mohou být společně s šedou vodou po predčištění v septiku nebo kořenové čistírně znovu použity napríklad k závlahám.

\section{ZÁVLAHY}

Jak již bylo uvedeno výše, odpadní vody se v některých státech, jako je např. USA, Austrálie, Izrael, Švédsko, Holandsko, běžně na závlahy parků a zemědělských ploch používají. Využívání přečištěných odpadních vod k vyšší produkci $\checkmark$ zemědělství (plantáže rychle rostoucích dřevin, ovocnářské sady) koreluje s implementací pojetí trvale udržitelného rozvoje. Vyšší využití těchto vod znamená snižení rizika znečištění povrchových či podzemních vod živinami, lepší nakládání s vodou v krajině a snížení nákladů na hnojení. [27].

Co se legislativy týče, je závlaha (i vyčištěnou) odpadní vodou brána jako vypouštění do vod podzemních a vodoprávní úrady ji nechtějí povolovat (a to i když se jedná jen o samostatnou šedou vodu bez produktů lidského metabolismu) a vyžadují při tom vyjádření hydrogeologa [3]. Kvalitu vod používaných pro závlahy řeší ČSN 757143 Jakost vody pro závlahu.

\section{RIZIKA SPOJENÁ S VYUŽÍVÁNÍM ODPADNÍCH VOD}

Nesmíme zapomínat na rizika spojená s používáním odpadních vod. Jde o riziko spojené s výskytem mikropolutantů (PPCPs - pharmaceuticals and personal care products) a o riziko hygienické.

Eliminaci hygienických rizik legislativně reší napríklad Ministerstvo zdravotnictví státu Washington, které umožňuje použivání šedých vod pouze k podpovrchovému zavlažování, a to pouze ve vegetačním období. Zákon s platností od roku 2011 rozlišuje vody z hlediska znečištujuících látek na světle šedé a tmavě šedé. Světle šedé vody mají nízký obsah patogenů, chemikálií, tuků, olejů, maziva pocházející z koupelen, sprch, van, praček. Tmavě šedé vody pocházejí z kuchyňských dřezů, myček nádobí, technických umyvadel, a tudíž obsahují mnohem vyšší koncentrace patogenů, chemikálií, tuků, olejů a maziv [28].

Hygienické riziko Ize velmi dobře vyřešit použitím vody pro kapkovou závlahu nebo obecně do podmoku, kdy riziko infekce z aerosolů eliminujeme.

Dalším rizikem je přenos mikropolutantů na zavlažovanou půdu a riziko kontaminace pěstovaných plodin [29]. Zde je možné diskutovat o tom, co se děje s mikropolutanty ve vodních tocích, kam je voda z čistíren odpadních vod vypouštěna. Pak je tu otázka biologické rozložitelnosti některých mikropolutantů, které se v pưdě rozkládají rychleji než ve vodě, i když je zřejmé, že doba kontaktu s půdou nebude při běžném způsobu závlahy velká. Z tohoto důvodu je asi nejprijijatelnější a nejbezpečnější způsob využití šedé vody pro závlahy v parcích, pro závlahy rychle rostoucích dřevin [27] a nově vysazovaných lesů.

\section{PŘíKLADY REALIZACÍ V ČESKÉ REPUBLICE}

V ČR se budování systémů využívajících šedé vody zvolna rozšiřuje. Individuálních systémů, které si lidé dělají svépomocí, bude hlavně na venkově již spousty. Co se týče větších instalací, již před sedmi lety se prvním objektem v ČR, který komplexně využívá šedé vody, stal hotel Mosaic House v Praze 2. Díky systému využití šedé vody s rekuperací tepla se stal první certifikovanou budovou BREEM In Use s hodnocením Excellent $v$ České republice. Čištění šedých vod zde zajištuje systém Pontos AquaCycle (fa. Hansgrohe). Jedná se o biologické čištění pomocí nárostové biomasy na molitanové drti v provzdušňovaných nádržích. Dalšími aplikacemi je pak vzdělávací centrum Rozmarýnek v Brně nebo hotel Galant v Mikulově, který k čištění šedých vod využívá systému AQUALOOP (fa. ASIO), kdy je voda po biologickém čištění filtrována přes membrány.

Vzhledem k tomu, že dodatečné budování dvojích rozvodů vody není jednoduché a je i finančně nákladné, je budování systémů nakládání s šedými vodami spíše výzvou pro novostavby. Z tohoto důvodu byl proveden průzkum mezi zástupci nejsilnějších rezidenčních developerů v Praze s otázkou, jak se jejich společnost k myšlence znovuvyužití šedých vod staví. Jejich odpovědi Ize v zásadě rozdělit do třech kategorií:

1. Nejsilnější z rezidenčních developerů v Praze - Central Group (21\% podíl na trhu $\checkmark$ prodaných bytech) - doposud žádné zrealizované ani naplánované projekty využívající systému znovuvyužití šedých vod nemá a ani v nejbližší době o něčem takovém prý neuvažují. Podobnou odpověd’ jsme obdrželi i od firmy Star Group.

2. Současná situace ve výstavbě nových bytových domů se nachází spíše v rovině zachytit veškerou srážkovou vodu, např. pomocí speciálních podzemních vsakovacích košů a využít ji k závlahám společných travnatých ploch v okolí novostavby nebo zachycenou srážkovou vodu použít k zavlažování zelených střech. S takovými projekty pracuje např. společnost Trigema (Chytré bydlení Horní Měcholupy), firma Daramis nebo firma M \& K Real Estate.

3. Nejdále se v oblasti znovuvyužití šedých vod zatím dostala firma Skanska Reality (s $8 \%$ prodaných bytů je 3. nejsilnějším rezidenčním developerem v Praze). V říjnu 2015 zahájila prodej prvního bytového domu v ČR Botanica K v Praze 5 v Jinonicích, který využívá systém pro hospodaření s šedou vodou. Voda z umyvadel, van a sprch je po přečištění využívána pro splachování toalet. Díky tomuto řešení bytová novostavba uspoří až 6000 litrů pitné vody denně. U domu je navíc umístěna akumulační nádrž pro zachycování srážkových vod, jenž mohou být dále využity pro zalévání zeleně v okolí domu.

\section{ZÁVĚR}

Vzhledem k předpokládaným výkyvům v distribuci srážek a možným obdobím sucha se autoři v článku pokoušeli zamyslet nad možnými úsporami pitné vody a rozumným znovuvyužíváním šedé vody a vyčištěné odpadní vody. Článek měl přispět k otevření diskuse nad touto problematikou.

\section{Literatura}

[1] Dostupné z: http://ekonomika.idnes.cz/diskusni-porad-rozstrel-s-ministrem-zivotniho-prostredirichardem-brabcem-17k-/ekonomika.aspx?c=A170116_141237_ekonomika_fih

[2] Dostupné z: http://www.tretiruka.cz/news/francie-testuje-ekologicke-pisoary-ktere-nepotrebujinapojeni-na-kanalizace/

[3] PLOTĚNÝ, K. Závlaha odpadními vodami a naše současná legislativa. Vodníhospodářství, 2016, roč. 66 č. 10, s. 24.

[4] KOŽǐ̌̌EK, F. Šedé vody z pohledu hygienika a legislativy. Sovak, 2012, č. 2, s. 14

[5] Dostupné z: http://www.rozhlas.cz/dvojka/kupredudominulosti/_zprava/vaclav-cilek-svetu-hrozi-suchoa-u-nas-az-50-vody-z-potrubi-zbytecne-unika--1489286

[6] Dostupné z: http://www.vhs-sro.cz/cs/co-vedet-o-vode/spotrebitelum-vody/spotreba-vody.html

[7] Dostupné z: http://www.aquainfo.cz/aqua-united/svetovy-den-vody/

[8] Dostupné z: http://www.grida.no/publications/et/ep5/page/2823.aspx

[9] Dostupné z: (http://www.scientificamerican.com/article/human-urine-is-an-effective-fertilizer/)

[10] Dostupné z: http://motherboard.vice.com/read/turns-out-that-using-human-poop-to-fertilizecrops-might-not-be-such-a-great-ide) 
[11] ČSN 465735 - Prưmyslové komposty, vyhláška č. 341/2008 Sb, o podrobnostech nakládán s biologicky rozložitelnými odpady a o změně vyhlášky č. 294/2005 Sb., o podmínkách ukládán odpadů na skládky a jejich využíiání na povrchu terénu a změně vyhlášky č. 383/2001 Sb. o podrobnostech nakládání s odpady, (vyhláška o podrobnostech nakládání s biologicky rozložitelnými odpady), v platném znění.

[12] Dostupné z: http://www.qia.cz/shop/select_det.php?id_vyrobek=491\&sada=1\&str=2\&skupina_ back $=0 \& k$ lic $=\&$ kod $=\& o d=0 \& d o=100000 \&$ razeni $=$ Nazev\&rozsah $=$

[13] Dostupné z: http://rodinnezahrady.cz/horky-kompost/

[14] HANČ, A. a PLÍVA, P. Vermikompostování bioodpadů. Certifikovaná metodika. Praha: Česká zemědělská univerzita $\vee$ Praze, 2013, s. 1-36.

[15] Dostupné z: http://www.rodalesorganiclife.com/garden/should-you-compost-your-poop

[16] Dostupné z: http://biom.cz/cz/odborne-clanky/odpovedi-na-dotazy-k-domovnimu-kompostovani [17] Nařizením Evropského parlamentu a Rady (ES) č. 1980/2000. (Nařizením Evropského parlamentu a Rady (ES) č. 1980/2000 ze dne 17. července 2000 o revidovaném systému Společenství pro udělován ekoznačky).

[18] Dostupné z: http://www.cenia.cz/web/www/webpub2.nsf/\$pid/CENMSFNRQD65/\$FILE/CENIA_typy \%20znaceni04.pdf

[19] Zákon č. 183/2006 Sb. o územním plánování a stavebním rádu (stavení zákon) - znění dle 91/2016. [20] Zákon č. 89/2012 Sb. občanský zákoník, v platném znění.

[21] Zákon č. 254/2001 Sb. zákon o vodách a o změně některých zákonů (vodní zákon), v platném znění.

[22] Vyhláška č. 474/2000 Sb. o stanovení požadavků na hnojiva, v platném znění.

[23] ČSN 465735 - Průmyslové komposty.

[24] Zákon č. 185/2001 Sb., o odpadech a o změně některých dalších zákonů, v platném znění.

[25] Vyhláška č.341/2008 Sb. o podrobnostech nakládání s biologicky rozložitelnými odpady a o změně vyhlášky č. 294/2005 Sb., o podmínkách ukládání odpadů na skládky a jejich využivání na povrchu terénu a změně vyhlášky č. 383/2001 Sb., o podrobnostech nakládání s odpady (vyhláška o podrobnostech nakládání s biologicky rozložitelnými odpady), v platném znění.

[26] Dostupné z: https://www.czso.cz/csu/czso/3-zivotni-prostredi-vt3v69q7vi

[27] HNÁTKOVÁ, T. a ŠEREŠ, M. Kořenové čistírny odpadních vod a využití přečištěných odpadních vod - opatření pro snižování rizik sucha a eutrofizace povrchových zdrojů vody v návaznosti na zemědělskou výrobu. Vodní hospodářství, 2016, roč. 66, č. 8, s. 19-21.

[28] Dostupné z: http://www.doh.wa.gov/CommunityandEnvironment/WastewaterManagement/ GreywaterReuse

[29] MACKULAK, T. a kol. Možný prienik liečiv a drog zo stabilizovaného kalu priamo do rastlín. Sovak 2016, roč. 25 , č. 6, s. $4-5$.

\section{Autoři}

Ing. Martina Beránková

凶martina.berankova@vuv.cz

\section{Ing. Dagmar Vološinová}

凶dagmar.volosinova@vuv.cz

\section{Mgr. Lada Stejskalová}

凶lada.stejskalova@vuv.cz

\section{Ing. Elžbieta Čejková}

凶alzbeta.cejkova@vuv.cz

Výzkumný ústav vodohospodářský T. G. Masaryka, v. v. i.

Příspěvek prošel lektorským řízením.

\section{DRAIN OR RE-USE?}

\section{BERANKOVA, M.; VOLOSINOVA, D.; STEJSKALOVA, L.; CEJKOVA, E.}

TGM Water Research Institute, p. r. i.

Keywords: gray water - NoMix Toilet - re-use of wastewater

Now is the time when even in the Czech Republic we have to save water. In our households do not use it for flushing toilets, used water reuse for irrigation, etc. But we must not forget the risks associated with gray water re-use. 